\title{
Isolated porcine ovarian follicles as a model for the study of hormone and growth factor action on ovarian secretory activity
}

\author{
A V Sirotkin, A V Makarevich, J Kotwica ${ }^{1}$, P-G Marnet ${ }^{2}$, \\ H B Kwon ${ }^{3}$ and L Hetenyi
}

Research Institute of Animal Production, 94992 Nitra, Slovak Republic, ${ }^{1}$ Institute of Animal Reproduction and Food Research, 10-718 Olsztyn-Kortowo, Poland, ${ }^{2}$ Laboratoire de Recherches sur la Traite, INRA/ENSAR, 35042 Rennes Cedex, France and ${ }^{3}$ Department of Biology, Chonnam National University, Kwangju 500-757, Korea

(Requests for offprints should be addressed to A V Sirotkin)

\begin{abstract}
The aim of our in vitro experiments with isolated porcine ovarian follicles was to study the effects of gonadotropins, GH, IGF-I and oxytocin (OT) on release of ovarian steroid, OT, IGF-I, insulin-like growth factorbinding protein-3 (IGFBP-3), prostaglandin $\mathrm{F}$ (PGF), prostaglandin $\mathrm{E}$ (PGE) and cAMP.

It was found that quarters of ovarian follicles cultured for 8 days produced significant amounts of progesterone, estradiol-17 beta, OT and IGFBP-3 with peaks of accumulation from the 3 rd to the 8 th day of culture. Addition of serum promoted progesterone, estradiol and OT release, whilst accumulation of IGFBP-3 was maintained to a greater extent in serum-free medium.

GH $(10 \mathrm{ng} / \mathrm{ml}$ or above $)$ was able to inhibit androstenedione, OT, PGF and IGFBP-3, to stimulate IGF-I and cAMP, and to alter testosterone and PGE release by follicles cultured in serum-supplemented and/or serumfree medium. IGF-I (10 ng/ml or more) inhibited androstenedione and PGF secretion, stimulated testosterone, estradiol, OT and cAMP production, but did not influence progesterone, IGFBP-3 or PGE output in these condi-
\end{abstract}

tions. OT (100 ng/ml) was able to inhibit androstenedione and to stimulate testosterone, IGF-I, PGF and PGE, but not estradiol or IGFBP-3 release. A stimulatory effect of $\mathrm{LH}$ on progesterone and $\mathrm{OT}$ and an inhibitory influence of $\mathrm{LH}$ on estradiol secretion in the serumsupplemented medium were observed. FSH in these conditions stimulated OT, but not progesterone or estradiol secretion.

The use of this experimental model suggests the involvement of gonadotropins, OT, GH and IGF-I in the control of ovarian steroid and nonapeptide hormone, growth factor, growth factor-binding protein, prostaglandin and cyclic nucleotide production. The stimulatory effect of GH on IGF-I, and the stimulatory influence of IGF-I on OT, as well as coincidence of the majority of effects of IGF-I and OT, suggest the existence of a GH-IGF-I-OT axis. On the other hand, the different patterns of action of GH and IGF-I on OT, estrogen and IGFBP-3 suggest that part of the GH effect on ovarian cells is IGF-I independent.

Journal of Endocrinology (1998) 159, 313-321

\section{Introduction}

There is a growing body of evidence that ovarian function is controlled not only by gonadotropins (Hillier 1991, Sirotkin \& Nitray 1994b, Sirotkin et al. 1994, Erickson 1995, Erickson \& Danforth 1995), but also by other substances of hypophysial or extra-hypophysial origin. In particular, growth hormone (GH) (Jia et al. 1986, Sirotkin \& Nitray 1994a, Sirotkin \& Schaeffer 1995, Sirotkin 1996a), insulin-like growth factor-I (IGF-I) (Giudice 1992, Paton \& Collins 1992, Spicer \& Echternkamp 1995, Sirotkin \& Makarevich 1996), oxytocin (OT) (Wathes 1989, Schaeffer \& Sirotkin 1995, Sirotkin 1995, 1996b, Sirotkin et al. 1996) and prostaglandin (Dennfors et al. 1983, Satoh et al. 1984, Michael et al. 1994) can regulate gonadotropin receptors, secretion of growth factors, steroid and nonapeptide hormones, prostaglandin F2-alpha (PGF) and cyclic nucleotides by rodent, bovine and human ovarian cells.

In pigs, effects of gonadotropin (Hillier 1991, Sirotkin \& Nitray 1994b, Sirotkin et al. 1994, Erickson 1995, Erickson \& Danforth 1995), OT (Schaeffer \& Sirotkin 1995, Sirotkin 1995, 1996b, Sirotkin et al. 1996) and prostaglandin (Dodson \& Watson 1979, Michael et al. 1994) on ovarian secretions have been reported. On the other hand, there is very little information on the effects of GH and IGF-I on ovarian secretion in this species. Only an increase in IGF-I production after GH treatment, as well as a stimulatory influence of both GH and IGF-I on porcine ovarian steroidogenesis, has been reported (Giudice 1992, Spicer \& Echternkamp 1995). These data suggest indirectly that IGF-I is a mediator of GH action on 
ovarian steroid secretion. On the other hand, the influence of $\mathrm{GH}$ and IGF-I on porcine ovarian growth factorbinding protein, OT, prostaglandin and cyclic nucleotides, which may be also mediators of hormone and growth factor action, has not yet been studied.

To understand the role of various peptide hormones and related substances in the control of ovarian secretory activity, as well as to obtain indirect evidence on their possible inter-relationships, a comparison of their effects on the secretion of various substances by porcine ovarian cells is necessary.

Most in vitro studies of the ovary have been performed on cultured granulosa cells. It is known, however, that the complete, long-term production of ovarian secretions requires functional integrity of the theca and granulosa compartments of the follicle (Hillier 1991, Erickson 1995). In an attempt to find an adequate model for the study of ovarian steroidogenesis during follicular development and after gonadotropin treatment, several procedures for the culture of whole mouse (Boland et al. 1993, Spears et al. 1996), bovine (Staigmiller et al. 1982, Kruip \& Dieleman 1989), sheep (Terlou et al. 1988, Mann et al. 1992) and porcine (Dodson \& Watson 1979) ovarian follicles have been developed. In these systems, short-term $(3 \mathrm{~h}$ to 2 days) perfusion with oxygenated serum-supplemented medium is usual. These perfusion systems have been used to study inter-relationships between gonadotropin, steroid hormones and prostaglandins within the ovary. Follicles do not appear to have been used previously for the study of $\mathrm{GH}$, growth factors and their binding proteins, OT or intracellular messengers.

The aims of our study were: (1) to determine the value of isolated quarters of porcine ovarian follicles for longterm culture in serum-free or serum-supplemented medium and the production of hormones and other biologically active substances, and (2) to study the influence of GH, IGF-I, OT, luteinizing hormone (LH) and follicle-stimulating hormone (FSH) on growth factor, growth factor-binding protein, steroid and nonapeptide hormones, eicosanoid and cyclic nucleotide secretion by these follicles.

\section{Materials and Methods}

\section{Isolation and culture of ovarian follicles}

Ovaries from non-cycling, Slovakian white gilts, 180 days old, without visible reproductive abnormalities, were obtained at a local slaughterhouse. Ovarian follicles were collected and processed according to Golubev \& Zavertjajev (1989) with several modifications. Briefly, $1 \mathrm{~h}$ after slaughter the tissues surrounding the ovary were removed and the ovaries opened with scissors at the site of entry of blood vessels. The connective tissues inside the opened ovary were gradually broken with large surgical forceps in order to access the follicles. Follicles $3 \mathrm{~mm}$ in diameter without visible signs of atresia were pressed down and separated from the surrounding connective tissues with small forceps. They were collected in a Petri dish and washed four times in sterile Dulbecco's modified Eagle's medium/F-12 1:1 mixture (Sigma, St Louis, MO, USA) supplemented with $10 \%$ heat-inactivated fetal calf serum (FCS, University of Veterinary Medicine, Brno, Czech Republic), and $1 \%$ antibiotic-antimycotic solution (Sigma). The follicles were then cut with small scissors into four equal parts, and washed gently, avoiding detachment of granulosa cells from the follicular wall. Quarters of follicles were placed individually in 24-well plates (Beckton Dickinson GmbH, Heidelberg, Germany) with $2 \mathrm{ml}$ medium. In the first series of experiments (studies of hormone accumulation in follicle-conditioned medium) follicles were cultured for 8 days with or without FCS at $37.5{ }^{\circ} \mathrm{C}$ in humidified air. The incubation medium was collected on days $0,1,2,3,4,6$ and 8 of culture. Microscopical examination of the cultures after 8 days showed that granulosa cells remained attached to the follicular wall; only insignificant numbers of cells started to grow away separately. In the second series of experiments (studies of hormone and growth factor effects on secretory activity) follicles were cultured for 4 days in serumsupplemented and, in some cases, also in serum-free medium in the presence of recombinant porcine $\mathrm{GH}$ (rpSTH, Research and Development, Pittman-Moore Inc., Terre Haute, USA; 0, 10 or $0,10,100$ or $1000 \mathrm{ng} / \mathrm{ml}$ ), recombinant IGF-I (Calbiochem, Lucerne, Switzerland; 0,10 or $0,1,10$ or $100 \mathrm{ng} / \mathrm{ml}$ ), porcine LH (National Hormone and Pituitary Program, Ogden BioService Corp., Rockville, USA; 0 or $10 \mathrm{ng} / \mathrm{ml}$ ), porcine FSH (SPOFA, Prague, Czech Republic; 0 or $10 \mathrm{ng} / \mathrm{ml}$ ) or synthetic OT (Sigma; 0 or $100 \mathrm{ng} / \mathrm{ml}$ ). The blank control was represented by medium cultured without follicular tissue. After culture, the follicle quarters were weighed and the medium stored at $-20{ }^{\circ} \mathrm{C}$ until analysis.

\section{Immunoassay}

Hormone, growth factor-binding protein and prostaglandin concentrations in 25-100 $\mu \mathrm{l}$ incubation medium were determined in duplicate without extraction. Progesterone, androstenedione, testosterone, estradiol and insulin-like growth factor-binding protein-3 (IGFBP-3) were analyzed using commercial IRMA kits from DSL (Webster, TX, USA). The RIA kit for cAMP assay was from Immunotech (Marseille, France). PGF and prostaglandin $\mathrm{E}$ (PGE) were determined using an RIA kit from the Institute of Isotopes (Budapest, Hungary) or the RIA described previously (Cetta \& Goetz 1982, Chang et al. 1995). IGF-I was measured according to the method of Furlanetto et al. (1977). OT was determined using our RIA or EIA described previously (Kotwica \& Skarzynski 1993, Marnet et al. 1994). The characteristics of these assays are presented in Table 1. 
Table 1 Characteristics of immunoassays used in experiments

\begin{tabular}{|c|c|c|c|c|}
\hline & \multirow{2}{*}{$\begin{array}{l}\text { Specificity of assay } \\
\text { (cross-reactivity } \\
\text { of antiserum used) }\end{array}$} & \multirow{2}{*}{$\begin{array}{l}\text { Sensitivity } \\
\text { of assay } \\
(\mathrm{ng} / \mathrm{ml})\end{array}$} & \multicolumn{2}{|c|}{$\begin{array}{l}\text { Coefficient of } \\
\text { variation }\end{array}$} \\
\hline & & & $\begin{array}{l}\text { Intra- } \\
\text { assay }\end{array}$ & $\begin{array}{l}\text { Inter- } \\
\text { assay }\end{array}$ \\
\hline Assay & & & & \\
\hline Progesterone & $\begin{array}{l}<0 \cdot 001 \% \text { to cortisol, corticosterone, danazol, cortisol, androstenediol, } \\
\text { pregnenolone, estradiol, testosterone }\end{array}$ & $0 \cdot 12$ & $<8 \cdot 0$ & $<1$ \\
\hline Androstenedione & $\begin{array}{l}<0.33 \% \text { to androsterone, hydroxyprogesterone, isoandrosterone, cortisone, } \\
<0 \cdot 1 \% \text { to deoxycortisone, progesterone, corticosterone, cortisol, }<0.001 \% \text { to } \\
\text { estrone, estradiol }\end{array}$ & $0 \cdot 03$ & $<9 \cdot 8$ & $<5$ \\
\hline Testosterone & $\begin{array}{l}<5 \cdot 8 \% \text { to hydrotestosterone, androstenedione, hydroandrostenedione, } \\
\text { androstanedione, }<0 \cdot 14 \% \text { to androstanediol, androstenediol, }<0 \cdot 001 \% \text { to } \\
\text { progesterone, estradiol, estrone, estriol }\end{array}$ & $0 \cdot 08$ & $<9 \cdot 6$ & $<9 \cdot 1$ \\
\hline Estradiol & $\begin{array}{l}<0.01 \% \text { to dehydroepiandrosterone, progesterone, cortisol, danazol, } \\
\text { androsterone, testosterone, androstenedione, corticosterone, cortisone }\end{array}$ & $6 \cdot 5$ & $<9 \cdot 4$ & $<19$ \\
\hline PGF & $\begin{array}{l}<0 \cdot 01 \% \text { to PGA-1, PGA-2, PGB-1, PGB-2, }<0 \cdot 1 \% \text { to PGE- } 1, \text { PGE-2, } 66.0 \% \text { to } \\
\text { PGF- } 1,100 \% \text { to PGF-2 }\end{array}$ & 0.005 & $<7 \cdot 7$ & $<4 \cdot 3$ \\
\hline PGE & $\begin{array}{l}<28 \cdot 0 \% \text { to PGA- } 1,<7 \cdot 0 \% \text { to PGA- } 2,<0 \cdot 6 \% \text { to PGB- } 1,<1 \cdot 4 \% \text { to PGB-2, } \\
<5 \cdot 0 \% \text { to PGF- } 1,<1 \cdot 5 \% \text { to PGF- } 2,165 \% \text { to PGE- } 1,100 \% \text { to PGE-2 }\end{array}$ & $0 \cdot 015$ & $<7 \cdot 5$ & $<4 \cdot 0$ \\
\hline OT & $\begin{array}{l}<0 \cdot 4 \% \text { to arg-vasopressin, lys-vasopressin, isotocin, tocinioc acid, PGF-2, } \\
\text { pFSH, }<12 \cdot 5 \% \text { to Tyr-Pro-Leu-Gly- } \mathrm{NH}_{2}\end{array}$ & $0 \cdot 0015$ & $<14 \cdot 0$ & $<7 \cdot 6$ \\
\hline IGF-I & $\begin{array}{l}<0 \cdot 0-1 \% \text { to insulin, proinsulin, epidermal growth factor, OT, pGH, pLH, } \\
\text { pFSH, } 1 \cdot 9 \% \text { to IGF-II }\end{array}$ & $0 \cdot 0014$ & $<3 \cdot 4$ & $<8 \cdot 2$ \\
\hline IGFBP-3 & $\begin{array}{l}<0 \cdot 03 \% \text { to IGFBP-I, IGFBP-2, IGFBP-4, IGFBP-5, IGFBP-6, IGF-I, IGF-II, pGH, } \\
\text { pLH, pFSH, OT }\end{array}$ & $0 \cdot 5$ & $<3.9$ & $<1.9$ \\
\hline cAMP & $\begin{array}{l}<0 \cdot 4 \% \text { to } \mathrm{CGMP},<0 \cdot 7 \% \text { to } 5^{\prime} \mathrm{AMP},<7 \cdot 0 \% \text { to ATP, }<0 \cdot 2 \% \text { to ScGMP, } 100 \% \\
\text { to ScAMP, }<1500 \% \text { to cAMP }\end{array}$ & $0 \cdot 2$ & $<16 \cdot 0$ & $<11$ \\
\hline
\end{tabular}

\section{Statistics}

Each experimental group was represented by six cultures of follicles. The data shown are means obtained in three experiments using separate pools of ovaries. In each experiment the value of the blank control was subtracted from the values determined in follicle-conditioned medium to exclude non-specific background. Substance levels in the medium in the first series of experiments were expressed per $\mathrm{ml}$ medium. The rates of substance production in the second series of experiments were calculated per mg tissue/day. Significant differences between the experiments were evaluated using two-way ANOVA. When ANOVA indicated effects of treatments, experimental and control groups were compared by Duncan's multiple range test.

\section{Results}

Secretory activity of ovarian follicles cultured in serum-free and serum-supplemented medium

Accumulation of progesterone (Fig. 1a), estradiol (Fig. 1b), OT (Fig. 1c) and IGFBP-3 (Fig. 1d) in the medium from follicle incubation was observed. Peaks of steroid hormones in media without and with serum occurred at 3 and 4 days of culture respectively. The amounts of progestagen and estrogen which accumulated in serum-supplemented medium were approximately 2.5- and 2-fold higher respectively than in serum-free medium. A 4- to 5-fold increase in the ratio of progestagen to estrogen in both media from day 1 to days $6-8$ of incubation was noted (not shown).

OT concentration in the medium increased to day 8 of culture. The amount of OT which accumulated in serumsupplemented medium was 3.2-fold higher than that in serum-free medium.

IGFBP-3 level in the serum-supplemented medium increased, reaching a plateau at 3-6 days of culture, and decreased at the 8 th day of culture. The increase in IGFBP-3 concentration in serum-free medium continued after 3 days of culture, reaching maximal value at the end of the experiment (day 8). At this time the IGFBP-3 level was 2.7 times higher in the serum-free medium than in the presence of serum.

In contrast to progesterone, estradiol and OT, daily changes of concentration of other substances during culture were not observed. Accumulation of IGF-I, 

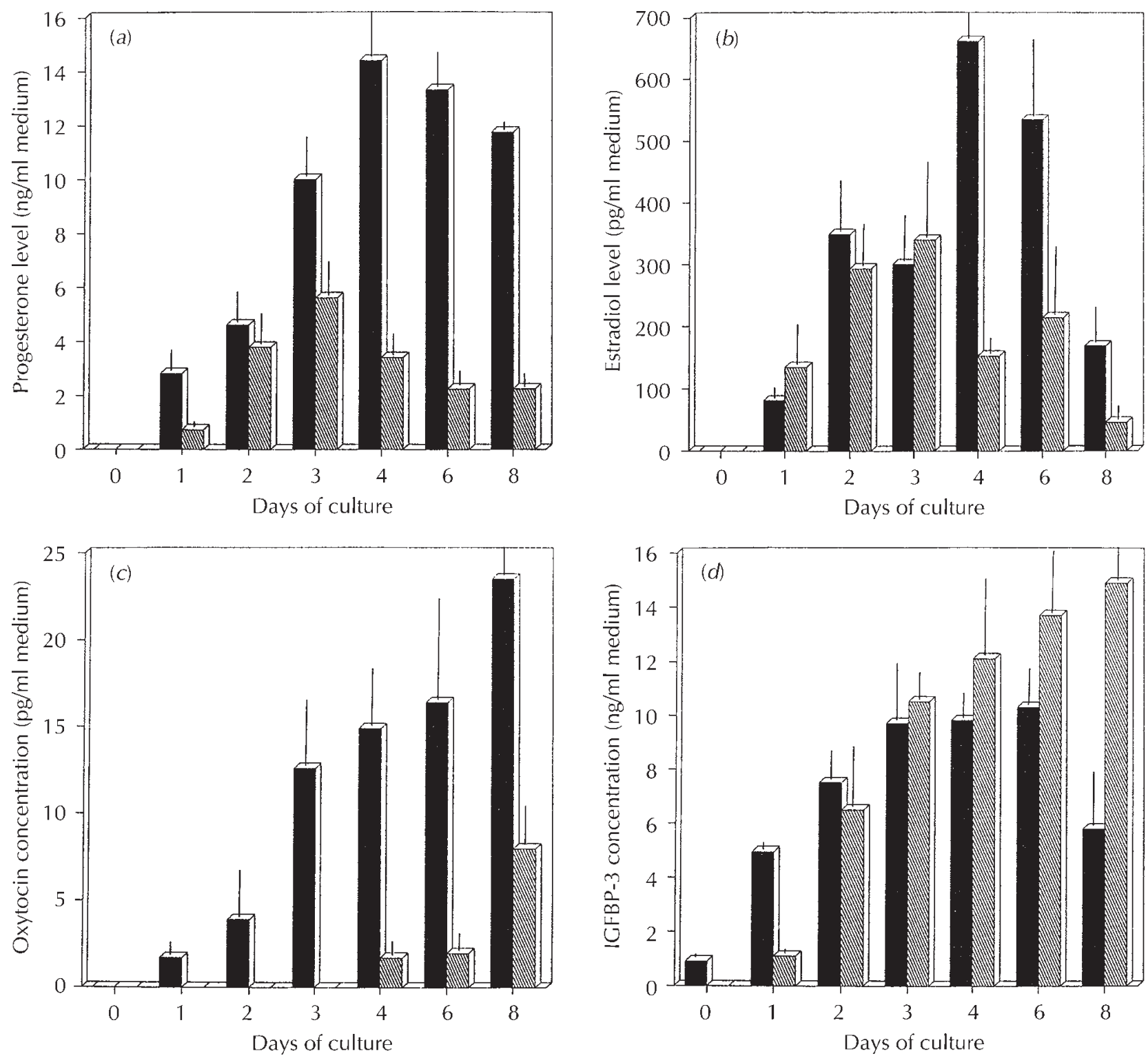

Figure 1 Accumulation of hormones in serum-supplemented (black bars) and serum-free (hatched bars) medium during culture of porcine ovarian follicles: (a) progesterone, (b) estradiol, (c) OT, (d) IGFBP-3. Values are means \pm S.E.M.

androstenedione, testosterone, PGF and cAMP were seen, however; their concentration increased, from zero levels before culture, up to day 4 of culture (Figs 2 and 3, Tables 2 and 3$)$.

\section{Effects of GH, IGF-I, LH, FSH and OT on secretory} activity of porcine ovarian follicles

$\mathrm{GH}(10$ or $100 \mathrm{ng} / \mathrm{ml})$ was able to inhibit androstenedione (in the serum-supplemented, but not in the serumfree medium, Fig. $2 a$, Table 2), OT (in the serumsupplemented medium, Table 3), IGFBP-3 (in the serum-supplemented, but not in the serum-free medium, Table 3), PGF (both in the serum-free and serumsupplemented medium, Table 3). GH given in these concentrations was also able to stimulate IGF-I (in the serum-supplemented, but not in serum-free medium, Table 3), and cAMP (in the serum-supplemented medium, Fig. 2b). GH increased testosterone release in the serum-free, but decreased it in the serum-supplemented medium (Table 2). No influence of GH on PGE release (either in the serum-free or serum-supplemented medium) or progesterone secretion (in the serumsupplemented medium) was observed (Tables 2 and 3). 


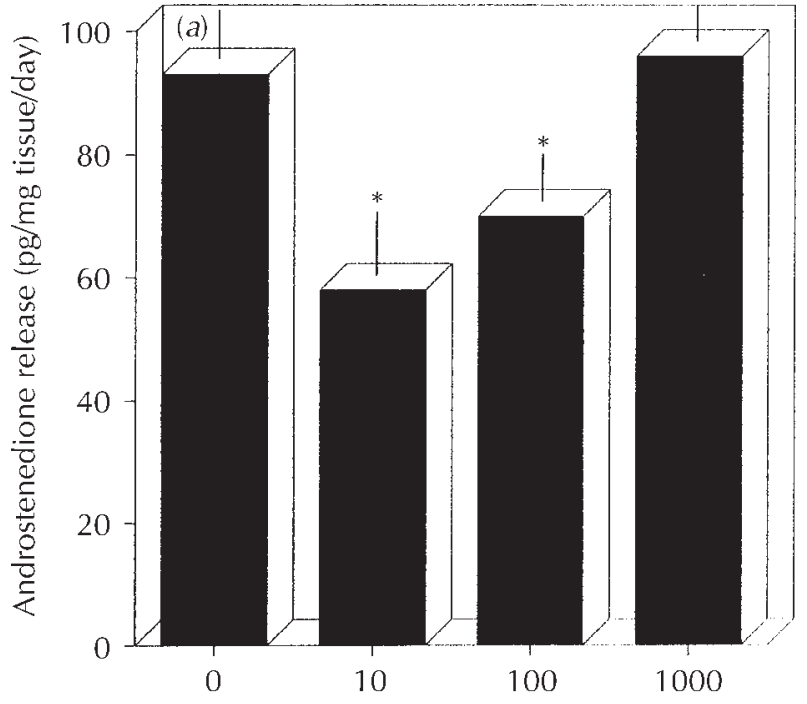

Preparation dose added ( $\mathrm{ng} / \mathrm{ml}$ medium)

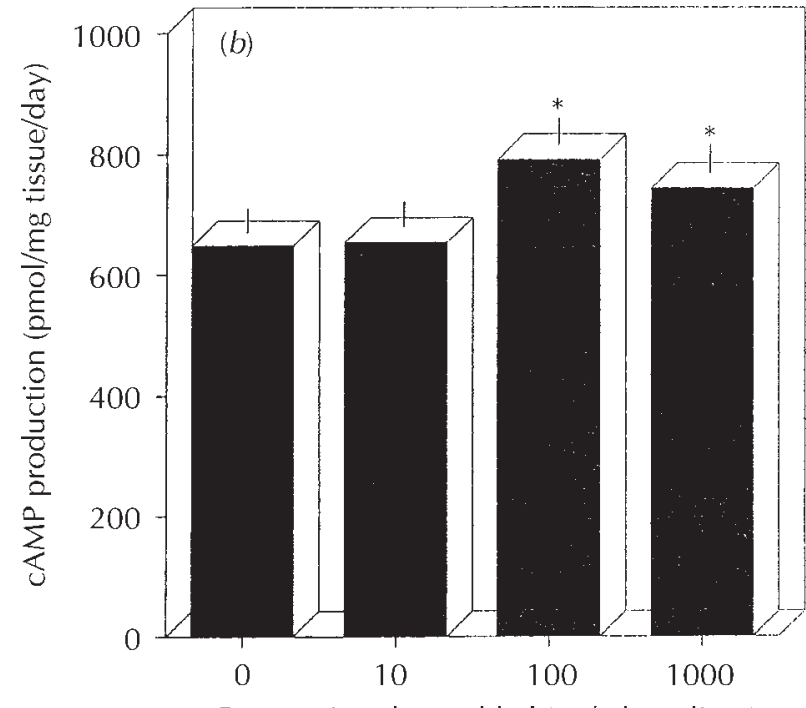

Preparation dose added ( $\mathrm{ng} / \mathrm{ml}$ medium)

Figure 2 Effect of porcine $\mathrm{GH}$ on (a) androstenedione and (b) cAMP production by cultured porcine ovarian follicles. Values are means \pm S.E.M. * Significant $(P<0 \cdot 05)$ difference compared with control (medium without $G H)$.

IGF-I (1 $\mathrm{ng} / \mathrm{ml}$ or above) inhibited output of androstenedione and PGF (both in the serum-free and serumsupplemented medium, Table 3, Fig. 3a). Furthermore, IGF-I stimulated testosterone, estradiol (both in the serum-free and in the serum-supplemented medium, Table 2), OT (in the serum-supplemented medium, Table 3), and cAMP (in the serum-supplemented medium, Fig. 3b). No effect of IGF-I on IGFBP-3, PGE (either in the presence or absence of serum, Table 3) or progesterone (in the presence of serum, Table 2) production was observed.

OT $(100 \mathrm{ng} / \mathrm{ml})$ was able to inhibit androstenedione and to stimulate testosterone and IGF-I, but not estradiol or IGFBP-3 release by follicles cultured either in the serum-free or serum-supplemented medium. Furthermore, OT stimulated both PGF and PGE production in
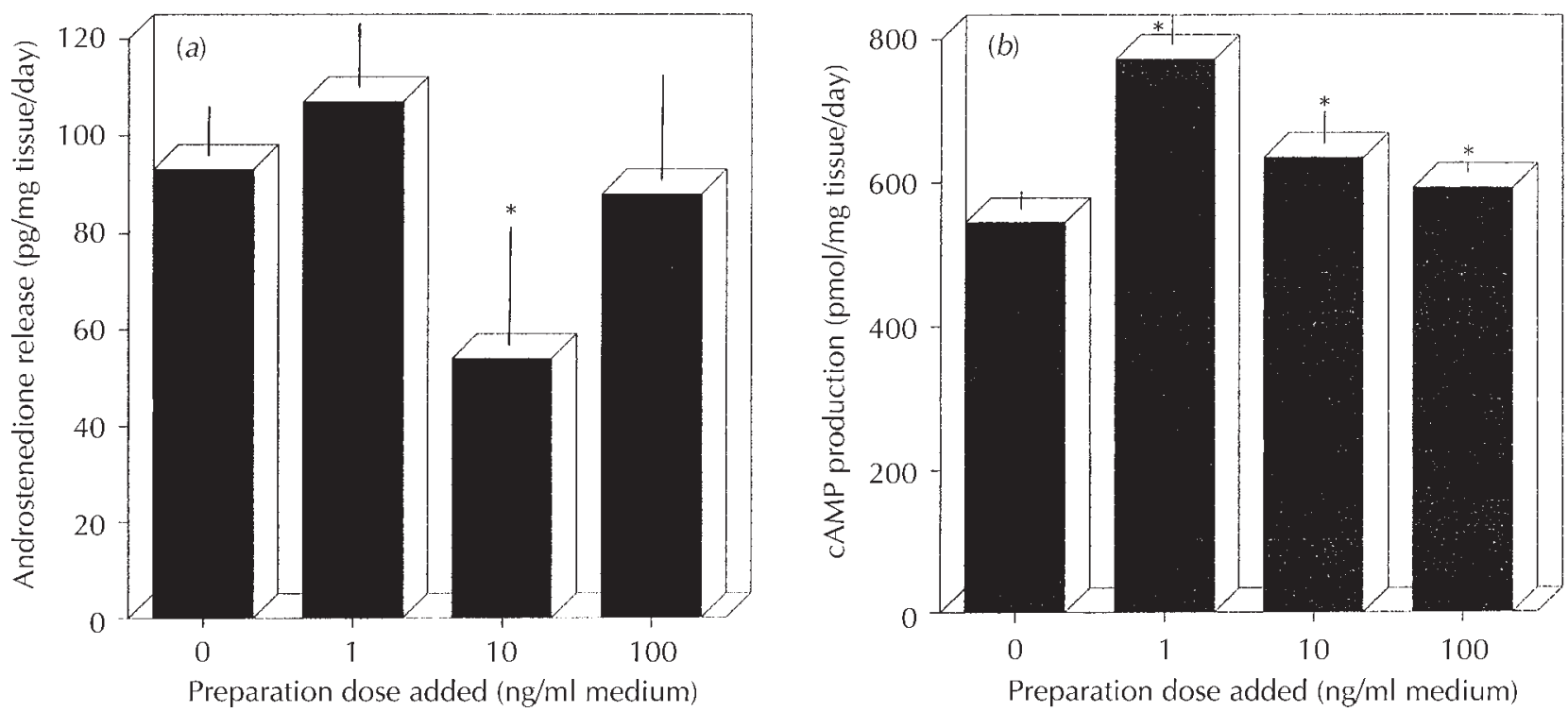

Figure 3 Effect of IGF-I on (a) androstenedione and (b) CAMP production by cultured porcine ovarian follicles. Values are means \pm S.E.M. ${ }^{*}$ Significant $(P<0 \cdot 05)$ difference compared with control (medium without IGF-I). 
Table 2 Effect of hormones and IGF-I on progesterone, androstenedione, testosterone and estradiol release by porcine ovarian follicles cultured in serum-free and serum-supplemented medium

\begin{tabular}{|c|c|c|c|c|c|}
\hline & \multirow{2}{*}{$\begin{array}{l}\text { Presence } \\
\text { of serum }\end{array}$} & \multicolumn{4}{|c|}{ Production $(\mathrm{ng} / \mathrm{mg}$ tissue per day \pm S.E.M.) } \\
\hline & & Progesterone & Androstenedione & Testosterone & Estradiol \\
\hline \multicolumn{6}{|l|}{ Treatment } \\
\hline None (control) & + & $1 \cdot 0 \pm 0 \cdot 1$ & $0 \cdot 6 \pm 0 \cdot 1$ & $2 \cdot 8 \pm 0 \cdot 3$ & $1 \cdot 3 \pm 0 \cdot 4$ \\
\hline \multirow[t]{2}{*}{$\mathrm{GH}(10 \mathrm{ng} / \mathrm{ml})$} & - & - & $0 \cdot 5 \pm 0 \cdot 1$ & $2 \cdot 2 \pm 0 \cdot 7^{*}$ & $1 \cdot 3 \pm 0 \cdot 2^{*}$ \\
\hline & + & $1 \cdot 0 \pm 0 \cdot 2$ & $0 \cdot 3 \pm 0 \cdot 1^{*}$ & $2 \cdot 2 \pm 0 \cdot 3^{*}$ & $1 \cdot 5 \pm 0 \cdot 4$ \\
\hline \multirow[t]{2}{*}{ LH (10 ng/ml) } & - & - & - & - & - \\
\hline & + & $1 \cdot 9 \pm 0 \cdot 7^{*}$ & - & - & $0 \cdot 9 \pm 0 \cdot 2^{*}$ \\
\hline \multirow[t]{2}{*}{ FSH $(10 \mathrm{ng} / \mathrm{ml})$} & - & - & - & - & - \\
\hline & + & $1 \cdot 1 \pm 0 \cdot 4$ & - & - & $1 \cdot 0 \pm 0 \cdot 1$ \\
\hline \multirow[t]{2}{*}{ OT (100 ng/ml) } & - & - & $0 \cdot 3 \pm 0 \cdot 1^{*}$ & $3 \cdot 5 \pm 0 \cdot 8^{*}$ & $0 \cdot 9 \pm 0 \cdot 4$ \\
\hline & + & - & $0 \cdot 5 \pm 0 \cdot 1$ & $4 \cdot 6 \pm 1 \cdot 7^{*}$ & $0.9 \pm 0.6$ \\
\hline
\end{tabular}

${ }^{*} P<0.05$ compared with control.

the serum-free medium, but not in the presence of serum (Tables 2 and 3).

LH stimulated progesterone and OT, while it inhibited estradiol secretion in the presence of serum. FSH in these conditions stimulated $\mathrm{OT}$, but not progesterone or estradiol secretion (Tables 2 and 3).

\section{Discussion}

The present paper appears to be the first report of the long-term culture of isolated porcine ovarian follicles in a static system. It was demonstrated that relatively long culture of follicle quarters in a static system in both serum-free and serum-supplemented medium without oxygenation can be used for studies of ovarian secretion.
Under our conditions follicles were able to survive and to maintain the granulosa cell layer and good secretory activity for several days. The use of quarters provides good contact for inner follicular cells with the medium. Consequently, they do not require the mobile, oxygenated medium, used for cultures of undisrupted follicles. Furthermore, our culture system allows the complete exclusion of serum, which may contain substances which interfere with treatments. On the other hand, serumsupplemented medium in all cases (except IGFBP-3 release) markedly promoted follicular secretion in our culture. In particular, the levels of accumulated progestagen, estrogen and OT in this medium were much higher, and were maintained longer, than those in serum-free medium. The ratio of progesterone to estradiol also increased during culture. No differences in this ratio

Table 3 Effect of hormones and IGF-I on (OT), IGF-I, IGFBP-3, PGF and PGE release by porcine ovarian follicles cultured in serum-free and serum-supplemented medium

\begin{tabular}{|c|c|c|c|c|c|c|}
\hline & \multirow{2}{*}{$\begin{array}{l}\text { Presence } \\
\text { of serum }\end{array}$} & \multicolumn{5}{|c|}{ Production $(\mathrm{ng} / \mathrm{mg}$ tissue per day \pm S.E.M. $)$} \\
\hline & & OT & IGF-I & IGFBP-3 & PGF & PGE \\
\hline \multicolumn{7}{|l|}{ Treatment } \\
\hline None (control) & + & $0 \cdot 5 \pm 0 \cdot 1$ & $6 \cdot 7 \pm 1 \cdot 8$ & $9 \cdot 0 \pm 0 \cdot 5$ & $0 \cdot 31 \pm 0 \cdot 02$ & $1 \cdot 03 \pm 0 \cdot 14$ \\
\hline \multirow[t]{2}{*}{$\mathrm{GH}(10 \mathrm{ng} / \mathrm{ml})$} & - & - & $21 \cdot 2 \pm 6 \cdot 7$ & $10 \cdot 0 \pm 1 \cdot 9$ & $0.22 \pm 0.03^{*}$ & $1 \cdot 82 \pm 0 \cdot 34$ \\
\hline & + & $0 \cdot 3 \pm 0 \cdot 1^{*}$ & $8 \cdot 6 \pm 1 \cdot 8^{*}$ & $8 \cdot 1 \pm 0 \cdot 6^{*}$ & $0 \cdot 23 \pm 0.03^{*}$ & $1 \cdot 09 \pm 0 \cdot 24$ \\
\hline \multirow[t]{2}{*}{$\mathrm{LH}(10 \mathrm{ng} / \mathrm{ml})$} & - & - & - & - & - & - \\
\hline & + & $4 \cdot 5 \pm 0 \cdot 4^{*}$ & - & - & - & - \\
\hline \multirow[t]{2}{*}{ FSH (10 ng/ml) } & - & - & - & - & - & - \\
\hline & + & $2 \cdot 6 \pm 0 \cdot 5^{*}$ & - & - & - & - \\
\hline \multirow[t]{2}{*}{ OT (100 ng/ml) } & - & - & $55 \cdot 5 \pm 12 \cdot 9^{*}$ & $12 \cdot 2 \pm 2 \cdot 9$ & $0.43 \pm 0.06^{*}$ & $2 \cdot 20 \pm 0 \cdot 40^{*}$ \\
\hline & + & - & $6 \cdot 0 \pm 1 \cdot 9$ & $9 \cdot 2 \pm 1 \cdot 7$ & $0 \cdot 25 \pm 0 \cdot 04$ & $1 \cdot 12 \pm 0 \cdot 15$ \\
\hline
\end{tabular}

${ }^{*} P<0 \cdot 05$ compared with control. 
between serum-free and serum-supplemented medium were found. This suggests that in both culture systems ovarian cells cannot avoid the spontaneous luteinization which is characterized by a decrease in estrogen and an increase in progestagen production (Hillier 1991, Paton \& Collins 1992). On the other hand, for the study of follicular secretion of IGFBP-3 the serum-free medium appears more suitable than the medium with serum. In the serum-free system IGFBP-I secretion was maintained longer than in the serum-supplemented medium (Fig. 1d). Furthermore, without serum IGFBP-3 and IGF-I were released in approximately equimolar ratios (similar to in vivo conditions, Giudice 1992), while the presence of serum promoted IGF-I, but not IGFBP-3 output (Table 3).

Our observations support available data on steroid (Hillier 1991, Paton \& Collins 1992), nonapeptide hormone (Wathes 1989), IGF-I, IGFBP-3 (Giudice 1992, Spicer \& Echternkamp 1995), prostaglandin (Dodson \& Watson 1979, Ainsworth et al. 1984, Tsang et al. 1988, Paton \& Collins 1992) and cyclic nucleotide (Paton \& Collins 1992, Sirotkin et al. 1994, Sirotkin 1996b) production by porcine ovarian cells.

Furthermore, our data on isolated porcine follicles correspond with previous reports on gonadotropins (Hillier 1991, Sirotkin \& Nitray 1994b, Sirotkin et al. 1994, Erickson 1995, Erickson \& Danforth 1995) and OT (Wathes 1989, Schaeffer \& Sirotkin 1995, Sirotkin 1995, 1996b, Sirotkin et al. 1996) influence on steroid, nonapeptide hormone, IGF-I and cyclic nucleotide production by porcine and bovine granulosa cells. The pattern of response and its expression in isolated follicles in our experiments were comparable with those reported previously for porcine granulosa cells. This is the first report on OT influence on ovarian PGE.

Furthermore, our present observations on isolated follicles confirm the available reports of an involvement of GH (Jia et al. 1986, Sirotkin \& Nitray 1994a, Sirotkin \& Schaeffer 1995, Sirotkin 1996a) and IGF-I (Giudice 1992, Paton \& Collins 1992, Spicer \& Echternkamp 1995, Sirotkin \& Makarevich 1996), in the control of growth factor, growth factor-binding protein and steroid production by porcine granulosa cells. In species other than pigs, effects of both GH (Sirotkin \& Nitray 1994a, Sirotkin \& Schaeffer 1995, Sirotkin 1996) and IGF-I (Schams 1987, Makarevich \& Sirotkin 1996, Makarevich et al. 1996, Sirotkin \& Makarevich 1996) on other ovarian substances (nonapeptide hormones, prostaglandin, cyclic nucleotides) have been reported. Our present data are the first demonstration of an involvement of GH and IGF-I in control of ovarian OT, prostaglandin and cAMP in pigs.

In particular it was found that in pigs, in contrast to other species, GH can inhibit ovarian OT, IGFBP-3 and PGF output. Inhibitory influences of GH on IGFBP-3 production suggest that $\mathrm{GH}$ can influence ovarian cells not only through stimulation of local IGF-I release, but also through reduction of ovarian IGF-I binding by IGFBP.

Since OT is a known regulator of steroid, peptide hormones and cyclic nucleotides in ruminant, human and porcine ovaries (Wathes 1989, Schaeffer \& Sirotkin 1995, Sirotkin 1995, 1996b, Sirotkin et al. 1996), it is possible that $\mathrm{OT}$ is the third messenger of $\mathrm{GH}$ action on the ovary. The inhibitory influence of GH on porcine follicular OT release (which was observed previously on porcine granulosa cells (Marnet et al. 1997), differs from the stimulatory effect of GH on ovarian OT in other species. It suggests the existence of species-specific differences in the control of ovarian nonapeptide hormone release.

The inhibitory influence of GH on ovarian PGF (but not on PGE), which is a known regulator of ovarian steroidogenesis, ovulation and luteogenesis (Dennfors et al. 1983, Satoh et al. 1984, Michael et al. 1994), suggests that PGF can also mediate GH action on the ovary.

The stimulatory action of GH on ovarian cAMP output, which is an important regulator of various ovarian functions, and which mediates effects of gonadotropins on the ovary (Hillier 1991, Paton \& Collins 1992) suggests also that cAMP may be a further mediator of GH effects on the ovary.

The evidence of a stimulatory action of GH on IGF-I release in our experiments supports the widely accepted hypothesis (Giudice 1992, Spicer \& Echterncamp 1995) that growth factors are the main mediators of $\mathrm{GH}$ action.

IGF-I in our experiments, as in experiments on ovarian cells of other animals (Adashi et al. 1986, Schams 1987, Makarevich \& Sirotkin 1996, Makarevich et al. 1996, Sirotkin \& Makarevich 1996), stimulated OT and cAMP output. The inhibitory influence of IGF-I on PGF release is the first observation of a growth factor effect on prostaglandin release. OT, PGF and cAMP may be potential mediators of IGF-I on the ovary.

In contrast to granulosa cells of pigs and other species (Giudice 1992, Spicer \& Echterncamp 1995), the follicles in our experiments responded to IGF-I with a reduced steroid hormone output. These data suggest that nonapeptide hormones, PGF, cAMP and steroid hormones can be involved in IGF-I action on the ovary and that theca as well as granulosa cells may be involved in the IGF-I action on ovarian steroidogenesis. It is possible that IGF-I induces production of some unknown factor(s) within the theca which can inhibit steroidogenesis in theca and/or granulosa cells through paracrine or autocrine mechanisms.

The present observations of an OT effect on steroid and IGF-I release by porcine follicles confirm previous reports of an OT action on the granulosa cells of pigs and other species (Wathes 1989, Schaeffer \& Sirotkin 1995, Sirotkin 1995, 1996b, Sirotkin et al. 1996). On the other hand, this is the first report of an OT influence on porcine IGF-I, IGFBP-3, PGF and PGE. These substances may be mediators of OT action on the ovarian cells. 
The effect of gonadotropins on steroid release is in agreement with similar observations on this and other species (Hillier 1991, Sirotkin \& Nitray 1994b, Sirotkin et al. 1994, Erickson 1995, Erickson \& Danforth 1995), while the stimulatory action of LH and FSH on ovarian OT secretion has previously only been demonstrated on bovine granulosa cells (Schams 1987, Wathes 1989). Since OT production increases during luteinization, and since it is a potent regulator of steroidogenesis (Wathes 1989), these data confirm the involvement of the gonadotropin-OT axis in the regulation of these processes.

The use of our experimental model suggests the involvement of gonadotropins, OT, GH and IGF-I in the control of ovarian steroid and nonapeptide hormones, growth factor, growth factor-binding protein, prostaglandin and cyclic nucleotide production. The interrelationships between these substances require further investigation. On the other hand, a comparison of the observations in our experiments and those in other laboratories may provide some indirect evidence. For example, the coincidence of effects of GH and IGF-I on PGF and cAMP observed in our experiments, as well as the influence of both PGF, (Dennfors et al. 1983, Satoh et al. 1984, Michael et al. 1994) and cAMP and related substances (Wathes 1989, Sirotkin 1996b) on steroid and nonapeptide hormone production suggest that effects of both GH and IGF-I on ovarian cells may be mediated through PGF- and/or cAMP-dependent intracellular mechanisms. Similarly, the stimulatory effect of GH on IGF-I, the stimulatory influence of IGF-I on OT, together with the convergence of the majority of effects of IGF-I and $\mathrm{OT}$ in our experiments suggest the existence of a GH-IGF-I-OT axis, which is involved in control of ovarian steroid and possibly prostaglandin and cAMP release. The stimulatory effect of gonadotropins on ovarian IGF-I (Adashi et al. 1986, Erickson 1995, Erickson \& Danforth 1995) and OT (Schams 1987. Wathes 1989, Table 3) suggest the existence of some cross-talk between the GH-IGF-I-OT and gonadotropin-IGF-I-OT systems. On the other hand, different patterns of action of GH and IGF-I on OT, estrogen and IGFBP-3 suggest that at least the part of GH effect on ovarian cells is IGF-I independent.

\section{Acknowledgements}

The authors thanks the National Hormone and Pituitary Program (Bethesda, MA USA), Drs L Underwood and J Van Wyk (University of North Carolina, Chapell Hill, USA) for kindly providing the antiserum against IGF-I, Dr G Kotwica (University of Agriculture and Technology, Olsztyn, Poland) for the gift of oxytocin antiserum, Prof. J Bulla for permanent support of these studies, Mrs T Civanova, K Tothova, Ms M Kubekova and B Ustianowska for technical assistance, and Dr M R Luck
(University of Nottingham, Sutton Bonington, UK) for critical reading and editing of the manuscript.

\section{References}

Adashi EY, Resnik CE, Svoboda ME \& Van Wyk JJ 1986 Somatomedin-C as an amplifier of follicle-stimulating hormone action enhanced accumulation of adenosine $3^{\prime}, 5^{\prime}$-monophosphate. Endocrinology 118 149-159.

Ainsworth L, Tsang BK, Marcus GJ \& Downey BR 1984 Prostaglandin production by dispersed granulosa and theca interna cells from porcine preovulatory follicles. Biology of Reproduction 31 115-121.

Boland NI, Humpherson PG, Leese HJ \& Gosden RG 1993 Pattern of lactate production and steroidogenesis during growth and maturation of mouse ovarian follicles in vitro. Biology of Reproduction 48 798-806.

Cetta F \& Goetz FWM 1982 Ovarian and plasma prostaglandin E and $\mathrm{F}$ levels in Brook trout (Salvelinus fontinalis) during pituitary-induced ovulation. Biology of Reproduction 27 1216-1221.

Chang KJ, Kim JW, Lee J, Im W-B, Kwon HB \& Schuetz AW 1995 Prostaglandin production and ovulation during exposure of amphibian ovarian follicles to gonadotropin or phorbol ester in vitro. General and Comparative Endocrinology 100 257-266.

Dennfors B, Hamberger L, Hillensjo T, Holmes P, Janson PO, Magnusson C \& Nilsson L 1983 Aspects concerning the role of prostaglandins for ovarian function. Acta Obstetrica et Gynecologica Scandinavica (Suppl 113) 31-41.

Dodson KS \& Watson J 1979 Effect of oestradiol-17 beta and gonadotropins on prostaglandin production by pre-ovulatory pig follicles superfused in vitro. Advances in Experimental Medicine and Biology 112 95-103.

Erickson GF 1995 The ovarian connection. In Reproductive Endocrinology, Surgery, and Technology, pp 1141-1160. Eds EY Adashi, JA Rock \& Z Rosenwars. New York: Raven Press. Erickson GF \& Danforth DR 1995 Ovarian control of follicle development. American Journal of Obstetrics and Gynecology 172 736-747.

Furlanetto R, Underwood L, Van Wyk J \& D’Ercole J 1977 Estimation of somatomedin-C levels in normal and patients with pituitary disease by radioimmunoassay. Journal of Clinical Investigation 60 648-657.

Giudice LC 1992 Insulin-like growth factors and ovarian follicular development. Endocrine Reviews 13 641-668.

Golubev AK \& Zavertjajev BP 1989 Methods of Culture of Ovarian Oocytes and Follicles, pp 1-35. Leningrad, VNIIRGZh.

Hillier SG 1991 Cellular basis of follicular endocrine function. In Ovarian Endocrinology, pp 73-105. Ed. SG Hillier. Oxford: Blackwell Scientific Publications.

Jia X-C, Kalmijn J \& Hsueh AJW 1986 Growth hormone enhances follicle-stimulating hormone-induced differentiation of cultured rat granulosa cells. Endocrinology 118 1401-1409.

Kotwica J \& Skarzynski D 1993 Influence of oxytocin removal from the corpus luteum on secretory function and duration of the estrous cycle in cattle. Journal of Reproduction and Fertility 97 411-417.

Kruip ThAM \& Dieleman SJ 1989 Intrinsic and extrinsic factors influencing steroid production in vitro by bovine follicles. Theriogenology 31 531-544.

Makarevich AV \& Sirotkin AV 1996 The influence and the mechanisms of action of EGF and IGF-I on rabbit reproductive processes in vitro. Abstracts of papers presented at the XIth Ovarian Workshop: Cell Growth, Apoptosis and Cancer (London, Canada). Abstract 34. Norwell, USA: Serono Symposia USA, Inc.

Makarevich AV, Sirotkin AV, Chrenek P \& Bulla J 1996 The role of growth factors in the regulation of rabbit reproductive processes in vitro. Journal of Physiology and Pharmacology 47 (Suppl 1) 167. 
Mann GE, McNeilly AS \& Baird DT 1992 Hormone production in vivo and in vitro from follicles at different stages of the estrous cycle in the sheep. Journal of Endocrinology 132 225-234.

Marnet PG, Volland H, Pradelles P, Grassi J \& Beaufils M 1994 Subpicogram determination of oxytocin by an enzyme immunoassay using acetylcholinesterase as label. Journal of Immunoassay 15 35-53.

Marnet PG, Makarevich AV, Sirotkin AV \& Bulla J 1997 Search for possible mediators of GH inhibitory action on IGFBP-3 and oxytocin in porcine granulosa cells. Journal of Reproduction and Fertility Abstract Series 2031.

Michael AE, Abayasekara DRE \& Webley GE 1994 Cellular mechanisms of luteolysis. Molecular and Cellular Endocrinology 99 R1-R9.

Paton AC \& Collins WP 1992 Differentiation processes of granulosa cells. Oxford Reviews in Reproductive Biology 14 169-223.

Satoh K, Kinoshita K \& Tsutsumi O 1984 Prostaglandins and ovulation. In Endocrinology, pp 321-325. Eds F Labrie \& L Proulx. Amsterdam: Elsevier.

Schaeffer H-J \& Sirotkin AV 1995 Release of insulin-like growth factor-I by luteinized human granulosa cells in vitro: regulation by growth hormone, oxytocin, steroids and cAMP-dependent intracellular mechanisms. Experimental and Clinical Endocrinology 103 361-366.

Schams D 1987 Luteal peptides and intracellular communication. Journal of Reproduction and Fertility (Suppl 34) 87-99.

Sirotkin AV 1995 In vitro effects of oxytocin and vasopressin on cyclic nucleotide production by bovine granulosa cells. Cellular Physiology and Biochemistry 5 380-384.

Sirotkin AV 1996a Direct action of growth hormone on bovine ovarian cells: effects on estradiol, oxytocin, vasopressin release by granulosa cells and on oocyte maturation and cleavage in vitro. Annales d'Endocrinologie 57 219-224.

Sirotkin AV 19966 Inter-relationships between nonapeptide hormones and cyclic nucleotides within cultured porcine granulosa cells. Journal of Endocrinology 150 343-348.

Sirotkin AV \& Nitray J 1994a Growth hormone and prolactin affect oxytocin, vasopressin, progesterone and cyclic nucleotide secretion by bovine granulosa cells in vitro. Journal of Endocrinology 143 417-422.

Sirotkin AV \& Nitray J $1994 b$ Puberty-related changes in hormone secretion and responsiveness to LH and dbcAMP of porcine granulosa cells in vitro. Animal Breeding 37 441-451.
Sirotkin AV \& Schaeffer H-J 1995 The effect of growth hormone on secretory activity of human granulosa cells in vitro. Endocrinology and Metabolism 2 215-220.

Sirotkin A \& Makarevich A 1996 Effect of growth factors on secretory functions of animal ovarian cells. Acta Zootechnica 52 79-88.

Sirotkin AV, Nitray J, Kolena J \& Bulla J 1994 Cooperation between $\mathrm{LH}-\mathrm{RH}$ and $\mathrm{LH}$ in the direct action on the ovary: LH-RH stimulation of LH-hCG receptors, basal and LH-induced cAMP and cGMP release by porcine granulosa cells in vitro. Cellular Signalling 6 135-140.

Sirotkin AV, Schaeffer H-J, Mlyncek M, Missik J \& Bulla J 1996 Oxytocin affect the release of steroids, insulin-like growth factor-I, prostaglandin F2 and cyclic nucleotides by human granulosa cells in vitro. Human Reproduction 11 152-155.

Spears N, de Bruin JP \& Gosden RG 1996 The establishment of follicular dominance in co-cultured mouse ovarian follicles. Journal of Reproduction and Fertility 106 1-6.

Spicer LJ \& Echternkamp SE 1995 The ovarian insulin-like growth factor system with an emphasis on domestic animals. Domestic Animal Endocrinology 12 223-245.

Staigmiller RB, England BG \& Webb R 1982 Estrogen secretion and gonadotropin binding by individual bovine follicles during estrous. Journal of Animal Science 55 1473-1481.

Terlou M, Berthold F \& Driancourt M-A 1988 Morphological and functional features of ovine follicles in perfusion with pulsatile hormone delivery. Reproduction, Nutrition, Development $\mathbf{2 8}$ 1093-1104.

Tsang BK, Arodi J, Li M, Ainsworth L, Srikandumar A \& Down EY 1988 Gonadotropic regulation of prostaglandin production by ovarian follicular cells of the pig. Biology of Reproduction $\mathbf{3 8}$ 627-635.

Wathes DC 1989 Oxytocin and vasopressin in the gonads. Oxford Reviews of Reproductive Biology 11 226-283.

Received 10 March 1997

Revised manuscript received 22 December 1997

Final version received 28 April 1998

Accepted 15 June 1998 